\title{
Deteksi Spesies Megalocytivirus pada Budidaya Ikan Laut di Kepulauan Riau
}

\author{
[Detection of Megalocytivirus Species on Marine Culture in Riau Islands] \\ Achmad Bahtiar Rifai ${ }^{1}$, Anak Agung Gede ${ }^{1}$,
Lucky Putra P Kusuma ${ }^{1}$, Yani Maulani
}

\author{
${ }^{1}$ Stasiun Karantina Ikan Kelas I Batam \\ ${ }^{2}$ Stasiun Karantina Ikan Kelas I Bandung
}

\begin{abstract}
Abstrak
Penyakit yang dapat menyebabkan kerugian ekonomi yang sangat tinggi adalah virus dan salah satunya adalah Megalocytivirus. Megalocytivirus mempunyai tiga spesies yaitu Infectious Spleen and Kidney Necrosis Virus (ISKNV), Red Sea Bream Iridovirus (RSIV), dan Turbot Redy Body Iridovirus (TRBIV). Gejala klinis pada ikan yang terinfeksi Megalocytivirus pada umumnya terlihat dari perubahan tingkah laku yaitu nafsu makan berkurang, berenang lemah, dan malas bergerak. Tubuh ikan yang terinfeksi terlihat lebih gelap baik pada permukaan tubuh sirip, dan bagian ekor. Metode uji yang digunakan pada penelitian ini adalah pengambilan sampel, pengujian histopatologi, deteksi spesies Megalocytivirus dengan polymerase chain reaction (PCR). Sampel ikan yang menunjukan gejala klinis diambil dari beberapa kabupaten/kota yang ada di kepulauan Riau antara lain Batam, Tanjungpinang, Bintan, Tanjung Balai Karimun dan Natuna. Sampel ikan adalah ikan kakap dan kerapu dari keramba jaring apung dan hatchery. Tujuan dari penelitian ini adalah mendeteksi spesies Megalocytivirus pada budidaya ikan laut yang ada di Kepulauan Riau. Pada uji histopatologi ditemukan lesio berupa badan inklusi, nekrosa, melano makrofag center pada hati, ginjal dan limpa. Badan inklusi dan nekrosa yang menyebar pada organ tersebut merupakan karakteristik Megalocytivirus. Hasil identifikasi PCR dengan menggunakan gen Major Capsid Protein pada panjang amplikon 777 bp berhasil mendeteksi Megalocytivirus. deteksi spesies Megalocytivirus dibeberapa Kabupaten/Kota di Kepulauan Riau menunjukan semua sampel ikan air laut terinfeksi ISKNV, sedangkan untuk spesies RSIV dan TRBIV tidak berhasil dideteksi pada penelitian ini. Infeksi Mengalocytivirus sudah menyebar pada budidaya ikan laut diseluruh kabupaten/Kota di Propinsi Kepulauan Riau. Spesies Megalocytivirus yang terdeteksi di Kepulauan Riau adalah ISKNV.
\end{abstract}

Kata kunci: ISKNV, Megalocytivirus, PCR, RSIV, TRBIV.

\section{Abstract}

Viruses that can caused very high economic losses were viruses and one of them was Megalocytivirus. Megalocytivirus has three species including the Infectious Spleen and Kidney Necrosis Virus (ISKNV), Red Sea Brid Iridovirus (RSIV), and Turbot Redy Body Iridovirus (TRBIV). The clinical summary of fish released by Megalocytivirus in general can be seen from changes in behavior, namely decreased appetite, weak swimming, and lazy to move. Fish body that looks better on the surface and on the fins and tail. The test methods used in this researched were sampling, histopathological testing, detection of Megalocytivirus species by polymerase chain reaction (PCR). Fish samples taken showed several samples of districts / cities in the Riau archipelago between Batam, Tanjungpinang, Bintan, Tanjung Balai Karimun and Natuna. Fish samples taken from snapper and grouper from floating net cages and hatcheries. In the histopathology test found lesio consists of inclusion bodies, necrosa, melano central macrophages in the liver, kidneys and spleen. The inclusion body and necrosa which spread to these organs are characteristic of Megalocytivirus. The results of approving PCR used the gene Major Capsid protein at the amplicon length $777 \mathrm{bp}$ managed to convince Megalocytivirus. The detection of Megalocytivirus species in several regencies / cities in the Riau Islands showed that all samples of sea water needed by ISKNV, while those of the RSIV and TRBIV species were not detected successfully in this researched. Mengalocytivirus infection has spread to marine fish 
cultivation in all districts / cities in the Riau Islands. The Megalocytivirus species added to the Riau Islands is ISKNV.

Keywords: ISKNV, Megalocytivirus, PCR, RSIV, TRBIV.

\section{Penulis Korespondensi}

Achmad Bahtiar Rifai | abherifai@gmail.com

\section{PENDAHULUAN}

Kepulauan Riau merupakan salah satu provinsi yang memiliki sumber daya kelautan dan perikanan terbesar di Indonesia. Jenis budidaya ikan yang menjadi unggulan adalah budidaya ikan air laut karena banyak diminati oleh nelayan di pesisir pantai. Salah satu kendala pada sektor perikanan budidaya adalah serangan penyakit yang sampai saat ini masih menjadi perhatian baik pemerintah pusat maupun pemerintah daerah. Beberapa faktor yang menyebabkan terjadinya serangan penyakit antara lain suhu, lingkungan dan polusi pada air (Lafferty et al. 2015). Penyakit patogen yang sering menginfeksi budidaya ikan antara lain parasit, jamur, bakteri, dan virus. Salah satu penyakit yang menyebabkan kerugian ekonomi yang sangat tinggi adalah Megalocytivirus.

Megalocytivirus merupakan salah satu genus terbaru dari famili Iridoviridae, genus selanjutnya yaitu Ranavirus, Lymphocytivirus dan Iridovirus (Kurita dan Nakajima 2012). Megalocytivirus memiliki tiga genus, dua diantaranya sudah terdeteksi di Indonesia, yakni
Infectious Spleen and Necrosis Virus (ISKNV) dan Red Sea Bream Iridovirus (RSIV) (Abidin 2013), sedangkan Turbot Redy Body Iridovirus (TRBIV) hanya ditemukan di Korea dan Cina (Shiu et al. 2018). Megalocytivirus dapat menyebabkan penyakit yang sistemik dan dapat menyebabkan kematian pada lebih dari 30 spesies ikan air laut konsumsi (Kurita et al. 2002).

Megalocytivirus pertama kali terdeteksi pada tahun 1990 di Jepang pada ikan kakap merah dan dinyatakan sebagai RSIV pada tahun 1991 (Inouye et al. 1992). Megalocytivirus telah dilaporkan di beberapa negara antara Iain Australia, Jepang, Korea, Cina, Thailand, Malaysia, Philipina, Singapura dan Indonesia (Go et al. 2006; Murwantoko, Handayani, dan Pratiwi 2009; Office International des Epizooties 2012). Kasus di Jepang biasanya terjadi pada musim panas dimana periode suhu air relatif menjadi tinggi. Sampai saat ini Megalocytivirus menginfeksi ikan air laut maupun ikan air tawar.

Gejala klinis pada ikan yang terinfeksi Megalocytivirus pada umumnya terlihat dari perubahan tingkah 
laku yaitu nafsu makan berkurang, berenangnya lemah, dan malas bergerak. Tubuh ikan yang terinfeksi terlihat lebih gelap baik pada permukaan maupun pada sirip dan bagian ekor (Mahardika, Zafran Yamamoto, dan Miyazaki 2004). Secara patologi anatomi terlihat anemia berat, ptechiae pada insang dan limpa serta ginjal membesar.

Secara umum pengobatan untuk Megalocytivirus belum ditemukan. Oleh karena itu, Kementerian Kelautan dan Perikanan berdasarkan Surat Keputusan Menteri no 81 tahun 2015 menjadikan Megalocytivirus sebagai hama penyakit ikan karantina golongan 1, pengawasan dan pencegahan yang ketat sangat diperlukan supaya tidak memperluas penyebaran ke daerah yang masih bebas dari agen penyakit Megalocytivirus. $\quad \mathrm{Di}$ samping pengawasan dan pencegahan diperlukan juga pendeteksian secara dini yang tepat dan cepat tentang penyakit tersebut. Oleh karena itu, pemerintah provinsi, daerah ataupun kota dituntut untuk siap mendukung setiap upaya pencegahan dan penularan terhadap agen penyakit Megalocytivirus agar industri perikanan budidaya air laut dan air tawar secara ekonomi tidak mengalami kerugian yang tinggi. Tujuan dari penelitian ini adalah untuk mendeteksi spesies Megalocytivirus pada budidaya ikan laut yang ada di Kepulauan Riau.

\section{BAHAN DAN METODE}

Pengambilan sampel dilakukan di beberapa kabupaten/kota di Propinsi Kepulauan Riau antara lain Batam, Tanjungpinang, Bintan, Tanjung Balai Karimun dan Natuna. Jenis sampel yang diambil adalah ikan kakap dan kerapu yang menunjukan gejala klinis Megalocytivirus. Sampel ikan tersebut kemudian dinekropsi untuk diambil organ limpa dan ginjal untuk dilakukan pengujian histopatologi dan Polymerase Chain Reaction (PCR).

\section{Uji Histopatologi}

Organ limpa dan ginjal untuk pengujian histopatologi kemudian dimasukan ke dalam formalin 10\%. Prosedur pembuatan preparat berdasarkan protokol yang telah ditetapkan oleh laboratorium patologi Fakultas Kedokteran Hewan Institut Pertanian Bogor antara lain organ yang dalam larutan fiksatif formalin 10\% kemudian dicuci dengan aquades, selanjutnya dilakukan perendaman dengan etanol dengan konsentrasi bertingkat. Penjernihan dengan larutan propanol dengan konsentrasi bertingkat, dilanjutkan dengan infiltrasi parafin dan embeding. Embeding adalah memasukan organ ke dalam parafin cair 
sampai mengeras dan dilanjutkan dengan pemotongan pada ketebalan $5 \mathrm{~mm}$ dengan mikrotom, lalu irisan ditempelkan pada gelas objek yang ditetesi albumin. Proses deparafinisasi atau perendaman jaringan yang sudah ditempelkan pada gelas objek dengan larutan $x y l o l$ secara berurutan selama 5 menit, kemudian dilakukan pewarnaan dengan haematoxylin dan eosin. Tahapan terakhir dari pembuatan preparat histopatologi yaitu jaringan ditetesi dengan entelan kemudian ditutup dengan kaca penutup. Pengamatan histopatologi dilakukan dengan melihat kerusakan sel ataupun jaringan menggunakan mikroskop dengan pembesaran 45 kali.

\section{Ekstraksi DNA Megalocytivirus}

Ekstraksi DNA dilakukan dengan menggunakan DNeasy ${ }^{\circledR}$ Blood and Tissue Kit (Qiagen Kit, Germany). Prosedur ekstraksi DNA dilakukan berdasarkan protokol dari perusahaan tersebut.

\section{Deteksi Megalocytivirus dengan Polymerase Chain Reaction (PCR)}

Deteksi Megalocytivirus menggunakan primer yang dirancang spesifik oleh Kurita dan Nakajima, (2012). Gen yang digunakan adalah Major Capsid Protein (MCP) dengan panjang amplikon 777 bp. Amplifikasi menggunakan primer forward dan reverse dengan urutan nukleotida sebagai berikut 5'AGGTGTCGGTGTCATTAACGACCTG3' dan reverse 5'TCTCAGGCATGCTGGGCGCAAAG-3'. Amplifikasi PCR dilakukan dengan total volume $25 \mu \mathrm{L}$ larutan reaksi yang terdiri dari $8.5 \mu \mathrm{L}$ RNase-free water, $12.5 \mu \mathrm{L}$ HotStarTaq Master Mix 2× (Qiagen), $1 \mu \mathrm{L}$ primer forward $(10 \mu \mathrm{M}), 1 \mu \mathrm{L}$ primer reverse $(10 \mu \mathrm{M})$ dan $2 \mu \mathrm{L}$ sampel DNA. Siklus amplifikasi diawali dengan pre denaturasi $94{ }^{\circ} \mathrm{C}$ selama 3 menit, dilanjutkan dengan 30 siklus yang terdiri dari denaturasi $94^{\circ} \mathrm{C}$ selama 30 detik, annealing $58^{\circ} \mathrm{C}$ selama 1 menit, ekstensi pada suhu $72{ }^{\circ} \mathrm{C}$ selama 1 menit dan akhir amplifikasi dilanjutkan dengan ekstensi akhir 1 siklus pada suhu $72^{\circ} \mathrm{C}$ selama 10 menit. Hasil PCR selanjutnya divisualisasi dengan elektroforesis menggunakan $1.5 \%$ agarose gel dan pewarnaan menggunakan SYBR Green $0.5 \mu \mathrm{g} / \mathrm{ml}$. Marker yang digunakan adalah DNA marker 100bp.

\section{Deteksi Spesies Megalocytivirus dengan Polymerase Chain Reaction (PCR)}

Sampel yang menunjukan hasil positif terhadap deteksi Megalocytivirus kemudian dilanjutkan dengan deteksi terhadap spesies Megalocytivirus 
Tabel 1 Daftar primer spesies Megalocytivirus

\begin{tabular}{llll}
\hline Gen & $\begin{array}{c}\text { Target } \\
\text { spesies }\end{array}$ & \multicolumn{1}{c}{ Sekuen primer $^{\mathbf{a}}$} & $\begin{array}{c}\text { Panjang } \\
\text { amplikon }^{\mathbf{a}}\end{array}$ \\
\hline MCP & RSIV & (F) 5'-CCCGCACTGACCAACGTGTCC-3' & $191 \mathrm{bp}$ \\
MCP & & (R) 5'-CACAGGGTGACTGAACCTCAGGTCG-3' & \\
& ISKNV & (F) 5'-GGTGGCCGGCATCACCAACGGC-3' & $415 \mathrm{bp}$ \\
MCP & (R) 5'-ACGGGGTGACTGAACCTG-3' & \\
& TRBIV & (F) 5'-TTCATCGACATCTCCGCTTTC-3' & $453 \mathrm{bp}$ \\
& & (R) 5'-TSTGACCGTTGGTGATACCGGAG-3' & \\
\hline
\end{tabular}

menggunakan metode PCR. Sekuen primer, target gen, panjang amplikon serta spesies Megalocytivirus yang ditampilkan pada tabel 1. Amplifikasi PCR sama dengan deteksi Megalocytivirus.

\section{HASIL DAN PEMBAHASAN}

Hasil

Perolehan Sampel

Sampel pada penelitian ini didapatkan dari beberapa kabupaten/kota di propinsi Kepulauan Riau antara lain: Batam, Tanjungpinang, Tanjung Balai Karimun dan Natuna. Jenis ikan yang diperoleh adalah kerapu dan kakap dengan gejala klinis antara lain mata menonjol, terdapat luka di badan, tubuh ikan terlihat gelap dan nafsu makan berkurang. Sedangkan secara patologi anatomi hati pucat, limpa dan ginjal mengalami pembengkakan dan banyak terdapat pelemakan di hati. Menurut Mahardika et al. (2004) gejala klinis yang terlihat pada Megalocytivirus adalah tubuh ikan terlihat lebih gelap baik pada permukaan maupun pada sirip dan bagian ekor. Jumlah sampel yang diperoleh di beberapa kabupaten di Propinsi Kepulauan Riau dapat dilihat pada Tabel 2.

\section{Uji Histopatologi}

$$
\text { Beberapa sampel yang }
$$
menunjukan gejala klinis Megalocytivirus kemudian dinekropsi untuk diambil organ limpa dan ginjal untuk pengujian histopatologi dan molekuler. Organ sampel yang diperiksa histopatologi dimasukan ke dalam larutan formalin $10 \%$ dan untuk molekuler disimpan dalam freezer pada suhu $-20^{\circ} \mathrm{C}$. Hasil histopatologi menunjukan adanya perubahan pada organ limpa dan ginjal antara lain badan inklusi, nekrosa, melano makrofag center, sel terlihat membesar. Hasil histopatologi ditampilkan pada Gambar 1. 
Tabel 2. Perolehan sampel ikan di Provinsi Kepulauan Riau.

\begin{tabular}{ccc}
\hline Kabupaten/kota & Jenis sampel & Total sampel \\
\hline Batam & Kerapu & 5 \\
Tanjungpinang & Kerapu & 3 \\
Tanjung Balai Karimun & Kakap putih & 5 \\
Natuna & Kerapu & 5 \\
\hline Total & & $\mathbf{1 8}$ \\
\hline
\end{tabular}
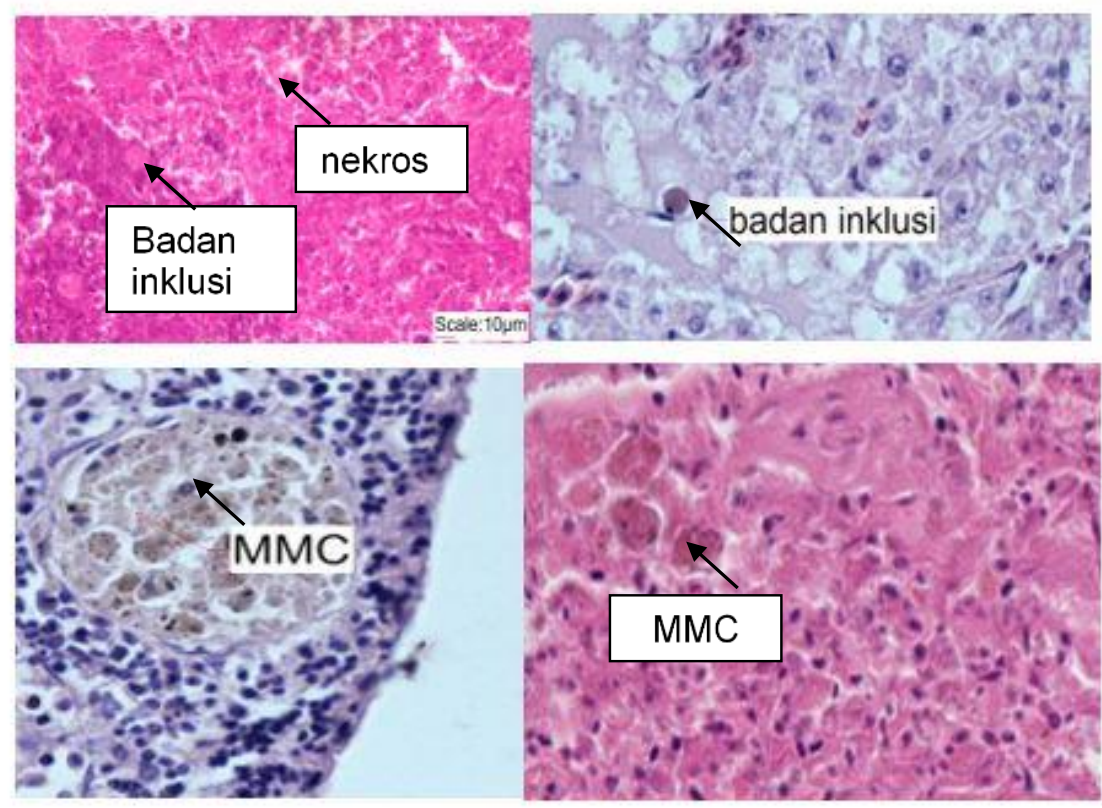

Gambar 1. Perubahan pada organ limpa dan ginjal antara lain badan inklusi, nekrosa dan MMC (melano makrofag center).

Deteksi Megalocytivirus dan

Spesiesnya.

Deteksi Megalocytivirus dan spesiesnya dilakukan menggunakan gen Major Capsid Protein dengan panjang amplikon 777 bp pada Megalocytivirus, 415 pada ISKNV dan 191 pada RSIV. Dari delapan belas total sampel yang diperoleh dari beberapa kabupaten di Propinsi Kepulauan Riau terdapat 10 sampel yang positif Megalocytivirus, sedangkan sisanya (8 sampel) negatif
Megalocytivirus. Masing-masing sampel yang positif Megalocytivirus kemudian dideteksi spesiesnya. Hasilnya, semua sampel yang positif terhadap Megalocytivirus, positif terinfeksi spesies ISKNV.

\section{Pembahasan}

Megalocytivirus merupakan salah satu genus baru dari family Iridoviridae yang diusulkan oleh Chinchar et al., 
(2005). Berdasarkan laporan kedelapan International Committee on Taxonomy of Virus (ICTV), genus Megalocytivirus tergabung dalam family iridoviridae bersama empat genus lainnya yaitu Iridovirus, Chloriridovirus, Ranavirus, dan Lymphocystivirus. Megalocytivirus dapat dibagi menjadi 3 spesies berdasarkan gen MCP dan ATPase yaitu RSIV, ISKNV dan TRBIV. Perbedaan asam amino di antara 3 spesies tersebut kecil, tetapi terdapat besaran/magnitude yang sama (Kurita dan Nakajima 2012).

Hasil histopatologi pada penelitian ini menunjukan sampel yang diperoleh terinfeksi Megalocytivirus, hal tersebut terlihat dari perubahan dan lesio antara lain badan inklusi dan nekrosa yang menyebar luas. Perubahan histologi yang terjadi pada organ dalam ikan khususnya limpa merupakan karakterisasi dari terjadinya infeksi Megalocytivirus, karena organ limpa merupakan target organ dari infeksi virus ini (Chao et al. 2004). Karakteristik yang paling jelas dari infeksi Megalocytivirus adalah nekrosa yang menyebar luas dan pembesaran sel, limpa dan ginjal adalah organ yang paling terpengaruh pada ikan terinfeksi (Kurita et al. 1998; Miyata et al. 1997; Oshima et al. 1998). Sel yang mengalami pembesaran ditemukan pada beragam jaringan, diantaranya limpa dan ginjal. Pembentukan sel yang membesar pada limpa, jantung, ginjal, hati dan insang dari ikan terserang merupakan karakteristik infeksi Megalocytivirus (Nakajima dan Sorimachi 1994).

Seluruh sampel (10 sampel) dari provinsi Kepulauan Riau menunjukan positif terinfeksi ISKNV, sedangkan untuk RSIV dan TRBIV menunjukan hasil yang negatif. Infectious Spleen and Kidney Necrosis Virus (ISKNV) pertama kali dideteksi pada ikan mandarin di Cina (He et al. 2000) dan tersebar luas di Asia Tenggara pada ikan laut maupun ikan air tawar. Gejala klinis yang terlihat antar spesies Megalocytivirus sangat identik, sehingga diagnosis tidak bisa berdasarkan pada gejala klinis. Salah satu uji konfirmasi untuk Megalocytivirus adalah PCR konvensional dan qPCR yang sampai saat ini masih digunakan.

Major Capsid Protein (MCP) merupakan gen yang digunakan untuk mendeteksi Megalocytivirus dan spesienya. Gen MCP merupakan gen yang sangat penting yang digunakan untuk menganalisis hubungan genetik di antara Family anggota Iridoviridae karena MCP merupakan protein struktural yang memiliki banyak bagianbagian penting yang membungkus informasi paling detail dari virus tersebut (Go et al. 2006). Major Capsid Protein $(M C P)$ terletak di antara lapisan amplop luar dan membran dalam sehingga $M C P$ merupakan suatu penanda yang sangat 
penting pada saat identifikasi secara molekuler (Dong et al. 2011).

\section{SIMPULAN}

Megalocytivirus terdeteksi di seluruh kabupaten/kota Propinsi Kepulauan Riau antara lain Batam, Tanjungpinang, Tanjung Bakai Karimun, dan Natuna. Seluruh sampel terinfeksi ISKNV, namun tidak terinfeksi RSIV dan TRBIV.

\section{PERSANTUNAN}

Terimakasih kepada Kepala Stasiun Karantina Ikan Pengendalian Mutu dan Keamanan Hasil Perikanan Kelas I Batam dan Bandung yang telah mengijinkan penulis untuk melakukan penelitian.

\section{DAFTAR PUSTAKA}

Abidin, La Ode Baytul. 2013. "Deteksi Molekuler Megalocytivirus pada Ikan Budidaya dengan Metode Polymerase Chain ReactionRestriction Fragment Length Polymorphism [Tesis]." Universitas Gadjah Mada.

Chao, Chia-Ben, Chun-Yao Chen, YuehYen Lai, Chan-Shing Lin, dan HungTu Huang. 2004. "Histological, ultrastructural, and in situ hybridization study on enlarged cells in grouper Epinephelus hybrids infected by grouper iridovirus in
Taiwan (TGIV)." Diseases of aquatic organisms 58(2-3):127-42.

Chinchar, VG, S. Essbauer, JG He, A. Hyatt, T. Miyazaki, V. Seligy, dan T. Williams. 2005. "Family Iridoviridae." in Virus Taxonomy Eighth Report of the International Committee on Taxonomy of Viruses, diedit oleh C. M. Fauquet, M. A. Mayo, J. Maniloff, U. Desselberger, dan L. A. B. T.-V. T. Ball. London (GB): Academic Press. Dong, C. F., X. P. Xiong, F. Shuang, S. P. Weng, J. Zhang, Y. Zhang, Y. -w. Luo, dan J. G. He. 2011. "Global Landscape of Structural Proteins of Infectious Spleen and Kidney Necrosis Virus." Journal of Virology 85(6):2869-77.

Go, Jeffrey, Malcolm Lancaster, Kylie Deece, Om Dhungyel, dan Richard Whittington. 2006. "The molecular epidemiology of iridovirus in Murray cod (Maccullochella peelii peelii) and dwarf gourami (Colisa lalia) from distant biogeographical regions suggests a link between trade in ornamental fish and emerging iridoviral diseases." Molecular and Cellular Probes 20(3-4):212-22.

He, J. G., S. P. Wang, K. Zeng, Z. J. Huang, dan S. M. Chan. 2000. "Systemic disease caused by an iridovirus-like agent in cultured 
mandarinfish, Siniperca chuatsi (Basilewsky), in China." Journal of Fish Diseases 23(3):219-22.

Inouye, Kiyoshi, Keisuke Yamano, Yukio Maeno, Kazuhiro Nakajima, Manabu Matsuoka, Yuji Wada, dan Minoru Sorimachi. 1992. "Iridovirus Infection of Cultured Red Sea Bream, Pagrus major." Fish Pathology 27(1):19-27.

Kurita, Jun dan Kazuhiro Nakajima. 2012. "Megalocytiviruses." Viruses 4(4):521-38.

Kurita, Jun, Kazuhiro Nakajima, Ikuo Hirono, dan Takashi Aoki. 1998. "Polymerase Chain Reaction (PCR) Amplification of DNA of Red Sea Bream Iridovirus (RSIV)." Fish Pathology 33(1):17-23.

Kurita, Jun, Kazuhiro Nakajima, Ikuo Hirono, dan Takashi Aoki. 2002. "Complete genome sequencing of Red Sea Bream Iridovirus (RSIV)." Fisheries science 68(sup2):111315.

Lafferty, Kevin D., C. Drew Harvell, Jon M. Conrad, Carolyn S. Friedman, Michael L. Kent, Armand M. Kuris, Eric N. Powell, Daniel Rondeau, dan Sonja M. Saksida. 2015. "Infectious Diseases Affect Marine Fisheries and Aquaculture Economics." Annual Review of Marine Science 7(1):471-96.
Mahardika, K., A. Zafran Yamamoto, dan T. Miyazaki. 2004. "Susceptibility of juvenile humpback grouper Cromileptes altivelis to grouper sleepy disease iridovirus (GSDIV)." Diseases of Aquatic Organisms 59:1-9.

Miyata, M., K. Matsuno, S. J. Jung, Y. Danayadol, dan T. Miyazaki. 1997. "Genetic similarity of iridoviruses from Japan and Thailand." Journal of Fish Diseases 20(2):127-34.

Murwantoko, Christina Retna Handayani, dan Rarastoeti Pratiwi. 2009. "Cloning and Sequence Analysis of Capsid Protein Gene of Iridovirus Indonesian Isolates." Indonesian Journal of Biotechnology 14(1):1117-23.

Nakajima, Kazuhiro dan Minoru Sorimachi. 1994. "Biological and Physico-chemical Properties of the Iridovirus Isolated from Cultured Red Sea Bream, Pagrus major." Fish Pathology 29(1):29-33.

Office International des Epizooties. 2012. Manual Diagnostic Test for Aquatic Animals. Paris (FR).

Oshima, S., Jl Hata, N. Hirasawa, T. Ohtaka, I. Hirono, T. Aoki, dan S. Yamashita. 1998. "Rapid diagnosis of red sea bream iridovirus infection using the polymerase chain reaction." Diseases of Aquatic 
Organisms 32:87-90.

Shiu, Jing-Yi, Jiann-Ruey Hong, ChenChun Ku, dan Chiu-Ming Wen. 2018. "Complete genome sequence and phylogenetic analysis of megalocytivirus RSIV-Ku: A natural recombination infectious spleen and kidney necrosis virus." Archives of Virology 163(4):1037-42. 